\title{
The World of the Child in Selected Poems by Joanna Kulmowa
}

\section{KEYWORDS}

miracle, dialogue, Joanna Kulmowa, Subjectivity, the child's world, tutoring, identity, Bettelheim, reading education, early school education, pre-school education

\begin{abstract}
"Children's need for miracles" has been accentuated as elements appearing in the selected poems by Joanna Kulmowa, which allow the child to be amazed by the world; they are a predicator to the appearance of tutoring. The astonishment with the world, as a place full of lyricism, enables the consolidation of identity by the emergence of the child's "I". Not judging and classifying. Subjectivity is emphasized: the seriousness of the child's world, understanding oneself, transforming the world, individuality, respect, acceptance, cooperation, responsibility, independence, sense of agency and dialogue. It was concluded that the main "miracle" is dialogue which: requires presence to be astonished by the world; raises the child's responsibility for another person; cannot be deprived of love; manifests itself in the "question-cry " for presence as a result of trust in the subject of the relationship.

The objectives of the study were: to define dialogue as Bettelheim's "miracle" in selected poems by J. Kulmowa; demonstrate that selected poems of J. Kulmowa are dialogical. The aim of the article was to: present the "miracles" in the child's world in selected poems by Joanna Kulmowa. The method of hermeneutics was used based on the methodology of Wolfgang Klafka. It seems important that so far the selected poetry of J. Kulmowa has not been interpreted in relation to Bettelheim's concept of "miracle" and its connection with the philosophy of dialogue, pedagogy and literary studies at the same time.
\end{abstract}

Adam Mickiewicz University Press, pp. 133-142

ISSN 2300-0422. DOI 10.14746/kse.2019.15.9

ORCID: https://orcid.org/0000-0001-7529-315X 


\section{Introduction}

Agnieszka Materne wrote about space as a place of memories that appear through the creation of poetic nostalgia (2017: 49). In this article a similar place, full of lyricism, will be the world of the child in the selected poems by Joanna Kulmowa. I will try to present all the "miracles" Bruno Bettelheim wrote about, exposed in selected poems by the 2010 honorary doctor of the University of Szczecin. Therefore, the term "miraculous" is intended for the "child's need for miracle" (Bettelheim, 1996: 83) and refers to all possible elements that exist in the world of J. Kulmowa's poems, which make the child wonder about the world. Astonishment with the world is part of the child's emerging identity: "The sense of separateness of one's own "I" from the environment is the basic dimension of identity, testifying to the sense of one's own uniqueness, difference and individuality" - wrote Agnieszka Cybal-Michalska (2006: 94). Every recipient and reader of J. Kulmowa's poetry, including a child, can find this sense of individuality in her works. It is the world presented in the poet's lyrical works that creates space for shaping one's own identity, bringing out the individuality of one's own " $\mathrm{I}$ ".

Therefore, the objectives of the research were: to present that selected poems of Joanna Kulmowa are dialogical; define dialogue as a "miracle" appearing in selected poems of Joanna Kulmowa. The following research problems have been identified: What is the manifestation of dialogicality in selected poems by Joanna Kulmowa?; What kind of dialogues appear in selected poems by Joanna Kulmowa?; What "miracles" appear in selected poems by Joanna Kulmowa?

The problem is significant because "In early childhood education, the child learns the difficult art of choosing values that determine the direction of "getting along" with the world and oneself" (Bałachowicz 2008: 70). Recognizing that the child's world in selected poems by Joanna Kulmowa may be a predicator of tutoring and the formation of identity while preserving subjectivity seems to be important, because the above mentioned elements contribute to the strengthening of a given person's opportunities in life.

Therefore, the subject of research is "miracularity" appearing in selected poems by Joanna Kulmowa, which defines the child's world and may be a good starting point to tutoring. Selected poems by the poet were examined in terms of the "miracles", their description and correlation with available pedagogical and philosophical literature. As a result, the significant role of dialogue as a "miracle" in the child's world has been emphasised. One can notice the implications of the philosophy of dialogue with selected poems by Joanna Kulmowa. 


\section{Theoretical background}

The space of a child's nature is a specific place full of cognitive curiosity, astonishment with the world and magical thinking. These elements of childhood can be described as Bettelheim's "miracles". The child's world is as important as the world of adults, after all, "A child is a human being, and its life is important and serious" - wrote Barbara Smolińska-Theiss (2014: 118). The seriousness and importance of a child's element can be described as a desire for self-control, which results from the need to "understand oneself in the world and the need to transform reality", which "are universal distinguishing features of the subject" (Bałachowicz 2013: 15). Therefore, a child in his world strives to distinguish his individuality, to notice his own uniqueness, but also accept differences and vices. It is an art that children learn throughout their entire life until they achieve the consolidation of identity. (Brzezińska 2005: 427).

School and kindergarten, places responsible for the child's upbringing, do not always help in achieving developmental tasks, as Agnieszka Gromkowska-Melosik shows: "Judging and classifying pupils is an integral part of the whole system of 'sorting' individuals in the society" (2007 : 36). This does not allow for the acceptance of differences, lack of skills, vices and dealing with failure. The child's world is dominated by the need to please teachers, to achieve good grades or their representations in the form of various symbols, e.g. suns. This situation emphasizes the need to create a place in the classroom for subjective treatment, mutual acceptance, which is possible. As Kinga Kuszak shows:

„In their relations with peers, children learn to present their own point of view, listen to what others have to say, and face the necessity of agreeing on positions and reaching common solutions. From their peers they learn how to act in order to gain acceptance, they learn how to accept and comply with the arrangements. As a result of contacts with other children, they mature to compromise in solutions, cooperation and co-responsibility" (2007: 14).

The quoted researcher describes peer tutoring based on research conducted in the Netherlands, from which the Polish education system can draw inspiration for the development of a child's nature. Thanks to the presented conceptualization of the role of a child as a teacher, one can see the mutual influence of children on each other. With the appearance of another child, the world of a child is enriched by the emergence of experiences and situations that allow for the development of independence. Independence appears in every period of human develop- 
ment. Jean-Paul Sartre wrote about this issue. His views were presented by Janina Świrko-Pilipczuk in her book entitled "Independence in philosophical views and concepts of man - pedagogical implications" (Świrko-Pilipczuk 2011). Here is a short fragment showing Jean Paul Sartre's position on the subject of human independence:

"His position overcame the existing patterns of describing human nature and introduced a significant and strong emphasis on human freedom and independence. First of all, he claimed that man cannot be defined, because originally he is nothing. Only later he becomes 'Somethng' [...]”' (Świrko-Pilipczuk 2011).

On the basis of this short passage, it can be said that independence is one of man's fundamental aspirations, it is what is yet to come, a process that gives freedom. Therefore, "the acquisition of a mature personality depends on the acquisition of the ability to direct oneself, to give one's actions the right direction" (Błasiak 2009: 126). It is about self-determination, taking responsibility for oneself, which allows the child to believe in him/herself and strengthens the sense of empowerment. A similar opinion is expressed by Zbyszko Melosik, who writes: "one can negotiate the shape of reality in which we live with young people, and in particular form their habit of making conscious choices in relation to the shape of one's own self" (2002: 144). This means that even older children, i.e. adolescents feel the need for a sense of empowerment and the awareness that they have self-control and can decide on the direction of their own existence.

The second basic function that appears in the relationship between children is their verbal communication. Dialogue, as Hanna Krauze-Sikorska writes, is a departure from "simple procedures and establishing a real relationship with others and searching for different determinants of learning difficulties" (2014: 25). It is therefore a sign of increased mental activity. Thanks to dialogue, the child creates new neural structures and connections that are conducive to the abandonment of the existing rules and allow for the emergence of new rules. Literature on human developmental psychology recognizes the huge role of speech in the child's world: "At preschool age [...] new areas of activity appear: communication with others through words, a tool of effective influence on the behaviour of others, and imagination, a tool of unrestricted mental activity" (Brzezińska, Appelt, Ziółkowska 2016: 164). One can see the co-existence of imagination next to speech, as the basic activity of a child in the world, starting from preschool age. Imagination is directly connected with the ability to fantasize. Fantasizing is one of the immanent features of a child. It is particularly evident in the work of 
Julian Tuwim, who wrote: "A baby is born, and after some time it starts to speak and almost immediately, without preparation, it speaks untruth. This means that fantasy is a natural phenomenon [...]. Children talk nonsense and want to hear nonsense. Then they grow out of it. Those who don't, become poets" (Słonimski, Tuwim 1990: 13).

In the next part of the article I will present selected poems by Joanna Kulmowa with reference to Bettelheim's concept of the "miracle" and the pedagogical and philosophical concept of a dialogue with subjectivity.

\section{Research procedure}

The research was carried out in accordance with the hermeneutical method research procedure, which is defined as a reflection on literary texts, extraction of their meaning (Wysocka 2004: 186). In particular, Wolfgang Klafka's method was used, according to which the following stages of the study were distinguished: 1 . Selection of volumes of poetry by Joanna Kulmowa; 2. Selectin of individual poems; 3 . Taking a position on the problem; 4 . Constant reference to the research problems in the course of research; 5. Semantic analysis of the highlighted poems; 6 . Determining the author's situation when writing the poems; 7. The use of sources supplementing the drawn conclusions; 8 . The use of syntactic means; 9. Exposing the main theses from the works; 10. Exposing ambiguity and contradictions in the analysed texts, if any; 11. Definition of the social and historical context of the researched poems. In the end, four poems by Joanna Kulmowa were examined, from the following volumes: "Dębołki" (Kulmowa 1998: 10); "Aporemy czyli rozmyślania przed lustrem" (Kulmowa 1971: 76); "Co się komu śni, a nawet i nie śni” (Kulmowa 2006: 9); "Zagapienie" (Kulmowa 2001: 4). The selected poems contain Bettelheim's "miracles" and are works for children. I believe that adults can also derive knowledge and joy from them. A constant element of the research procedure, which was highlighted in the fourth stage of the research, includes the research problems: What is the manifestation of dialogicality in the selected poems by Joanna Kulmowa?; What kind of dialogues appear in selected poems by Joanna Kulmowa?; What are the "miracles" that appear in selected poems by Joanna Kulmowa? The aim of the article is to enrich the pedagogical theory concerning the child's world in relation to the "miracles" appearing in selected poems by Joanna Kulmowa. Especially the dialogue. 


\section{Results}

This chapter will present the results of research on four poems with respect to the W. Klafka's methodology. This will include fragmentary interpretations of the results, according to the stages of research based on the aforementioned hermeneutical method.

The poem "Dębołki" [Oaklings] ${ }^{1}$ shows dialogicality. It manifests itself in the presence of the title "oaklings", which appear at nightfall. Thus, the "miracle" includes not only a dialogue with the reader/listener, but also the very fact of the appearance of "oaklings" as mysterious creatures - we do not really know who they are. This is the key element of their "miracle", i.e. their mysterious presence.

In this paragraph, I will focus on the author's situation which occurred when she was writing the analysed text (in accordance with the research procedure). The situation that accompanied the author at the time she was writing the examined text is connected with a random event in Joanna Kulmowa's life. The volume "Dębołki" was written two years after a difficult move from Strumiany near Szczecin to the Warsaw apartment of the Kulm family. Below I will present a supplement to the formulated conclusion.

Johann Mader's philosophy of dialogue was chosen as a complementary source. The thinker wrote about the philosophy of dialogue in the following way: "it is a way of thinking in which dialogue and meeting become a principle of philosophy" (Mader 2003: 4). This means that dialogue always requires someone's presence. Referring to idiographical reasons, it can be said that the "oaklings" also express their own presence. These creatures, created by Joanna Kulmowa, can be considered as res loquens, i.e. the Other (Gara 2009: 106). Someone transcendent and autonomous (ibid.), who disappears when the morning comes and appears at night. There are also causal relationships within and between the different verses. We can observe the implications between the expressions in the poem, e.g.

"The moon barely rises above the forest" [...

"When they are oak-founded" [...]

"And when the fog descends from the meadows in the morning" [...]

"They run away,

On the double, the oaklings!” (Kulmowa 1998: 10). ${ }^{2}$

\footnotetext{
1 The English titles of all the analysed poems have been translated by the translator.

2 Fragment of the poem „Dębołki” by J. Kulmowa, translated by the translator.
} 
The juxtaposed verses of the poem point to a mystery which is a valuable element of learning in the child's world. I believe that teachers and parents do not deprive children of the pleasure of meditation that B. Bettelheim wrote about: "Fairy tales leave it to the child's imagination to decide whether and how it should relate to what the story says about life and human nature" (Bettelheim 1996: 83). I will not do it either, and I will allow the reader's imagination to work. I will confine myself to presenting the key thesis of each of the lyrical works in question. Therefore, the main thesis of the J. Kulmowa's poem "Dębołki" is the occurrence of dialogue through the mere fact of the presence of the "oaklings", as a partner for dialogue, of "miracles" enabling one to be amazed by the world.

Due to the limitation in the number of characters used and so as not to exceed them, I am forced to present the remaining three poems in a short form. It will present the main thesis of these works together with a reference to complementary sources.

The next poem that I will discuss is a lyrical composition entitled "Zasypianie sikorek" [Titmice falling asleep]. It captures the following "miracles": dialogue, nature, the presence of the moment of falling asleep. How do the these elements of the depicted world relate to the sought-after dialogue? Emmanuel Levinas is a representative of the philosophy of dialogue, who distinguished res cogitans, or the Conscious (Gara 2009: 106). Referring directly to the work in question, one can conclude that the child is entitled to perceive the nestling as - the Conscious in the Other (res loquens). I would like to briefly discuss this claim. Namely, in the discussed poem, the nestling - an autonomous being - manifests identity, which induces a "continuous responsibility for another human being" (Ibid.: 107). This concept can be presented in the following manner: I am the same, similar, I also fall asleep when the sun sets, which leads to the claim that the person falling asleep is equally important. The main thesis of this lyrical work, therefore, is that dialogue appears as a "miracle" that awakens the child's responsibility for the other.

The poem entitled "Sprawiedliwość" [Justice], in the fragment entitled "1", emphasizes dialogue as the "miracle" in the child's world, next to: a stone, bread and flour. Below I will present a proposal of interpretation of this work in comparison with the philosophy of dialogue. Ferdinand Ebner wrote: "It is a characteristic feature of our times that all other triumphs and victories lead to defeat at the same time" (Ebner 2003: 18). In the proposed concept, this defeat is reflected in the stones that have been thrown, in excess, and there is no more flour left for bread. For F. Ebner, word is a gift from God, so it cannot be abused, or deprived of love (ibid.: 25). The main thesis in this poem is that dialogue is defined as "miraculous", and ceases to be dialogue when it is devoid of love. 
In the poem "Zagapiona jesień" [Autumn Belated] Joanna Kulmowa asks the question: "What should we do to make Autumn stay longer? Thus, the child's world is enriched with the "miraculous" dialogue with autumn. The "miracles" include: an orchard, wild wine, a cobweb, a butterfly, a cocoon, spiders. In the next part of this paragraph I will present the concept of dialogicality in the discussed lyrical piece, based on the philosophy of dialogue. Franz Rosenzweig wrote: "Revelation reaches its peak in an unfulfilled wish, in the cry of an open question" (Rosenzweig 2003: 34). The thesis proposed by the thinker can be used to describe the dialogue that has been embodied in the analysed poem by the "cry-question" about the presence of something. This means the presence of the title autumn. The situation presented in the lyrical work shows a desire to keep autumn for longer. It means a "cry-question" for autumn to stay a bit longer. The fundamental element of the presence is the trust that autumn can be stopped. Therefore, the presence may result from the trust that the subject of the relationship is endowed with. The main thesis of this poetic work is the "miracle" of dialogue manifested in the "question-cry" about the presence of autumn, which has beenendowed with trust.

\section{Discussion}

The results were compared only with the philosophy of dialogue. Therefore, in this chapter I will refer mainly to pedagogical literature, but also to philosophy or literature studies.

The dialogue dimension presented in the results referred to the "miraculous" world of the child: presence, love, responsibility for another person, the Conscious and the Other. Thus, we can sum up all the considerations based on the philosophy of dialogue citing Jaromir Brejdak as the ability to be open to another being (2015: 75). Karol Tarnowski adds that dialogue is a "bond of fidelity". (2015: 224), "It is about talking rather than about what is actually being said" (2015: 218).

The dialogicality of selected poems by Joanna Kulmowa is manifested in the form of such "miracles" as: dialogue, a "cry-question" and trust, autumn, orchard, wild wine, cobweb, butterfly, cocoon, spiders, stone, bread, flour, nature, the presence of the moment of falling asleep, "dębołki", the mystery of presence. The everyday life of some "miracles" allows us to use them in classes with children. Thus, the poetry presented by J. Kulmowa, apart from the dialogical dimension, gives the ordinary elements of everyday life a touch of magic. Alicja Baluch wrote about the language of archetypes that concretize "what is inexpressible and unclear. They testify to the existence of a dialogue between the unconscious and the conscious" 
(2016: 14). Therefore, pedagogy is closely connected with literature studies, because "spontaneity, the ad hoc nature of lyrical 'inspirations', which may be realized by just one faint motif, one poetic image" (Krzyżanowski 1984: 189) is constituted in the poetry of Joanna Kulmowa. This poetry is "filled with a sense of humour and serenity, it breathes optimism, it speaks with direct imagery and solar symbolism" (Chęcińska 2012: 9). The solar aspect defines presence as a way of moving towards and away from life and death. It is related to the desire to preserve its essential character.

Thus, it can be said that selected poems of J. Kulmowa are dialogical; the dialogue of J. Kulmowa's selected poems enables the emergence of peer tutoring in a situation when the listeners/readers are children of different developmental ages; the dialogue in the child's world is a dominating "miracle" that illustrates the subjectivity of a child. Dialogues that appear in selected poems by J. Kulmowa are not obvious, they require a child's inborn artistic intuition or the effort of an adult who was deprived of the possibility to experience art or admire the world. At the same time, these poems are amusing, spontaneous and teach symbolism through the magic of ordinary things. It is worth noting that Joanna Kulmowa's poetry has not yet been compared with pedagogy, literature studies and the philosophy of dialogue at the same time. I hope that this article will contribute to a deeper exploration of Kulmowa's poetry in classes at all levels of education, especially in the initial period.

\section{Bibliography}

Baluch A. (2016), Co warto wiedzieć o literaturze dla dzieci i młodzieży. [in:] U. Chęcińska (ed.), Dziecko i baśnie świata w kontekście wczesnej edukacji. Szczecin.

Bałachowicz J. (2008), Styl pracy nauczyciela klas początkowych a wsparcie rozwoju podmiotowego dziecka. [in:] Puślecki W. (ed.), Wspieranie rozwoju dzieci w procesie wczesnej edukacji. Wrocław.

Bałachowicz J. (2013), Tutoring w rozwoju podmiotowym dziecka. [in:] taże i Rowicka A. (ed.), Nowoczesny wychowawca - tutor, mentor, coach. Warsaw.

Bettelheim B. (1996), Cudowne i pożyteczne. O znaczeniach i wartościach baśni, transl. by Danek D. Warsaw.

Błasiak A. (2009), Wartości w procesie samowychowania, [in:] taże., Aksjologiczne aspekty procesu wychowania. Wybrane zagadnienia. Krakow.

Brejdak J. (2015), O solidarnej naturze osoby w ujęciu Józefa Tischnera i Maksa Schelera. [in:] Ks. Jarosław Jagiełło (ed.), Spory o naturę człowieka. Józefowi Tischnerowi w 15. rocznicę śmierci. Kielce.

Brzezińska A. (2005), Psychologiczne portrety człowieka. Praktyczna psychologia rozwojowa. Sopot. Brzezińska A., Appelt K., Ziółkowska B. (2016), Psychologia rozwoju człowieka. Sopot. 
Chęcińska U. (2012), Bibliografia i ikonobibliografia twórczości Joanny Kulmowej. Szczecin.

Cybal-Michalska A. (2006), Tożsamość młodzieży w perspektywie globalnego świata. Studium socjopedagogiczne. Poznań.

Ebner F. (2003), Fragmenty pneumatologiczne, transl. by B. Baran, transl. by J. Doktór. "Dominikańskie studium filozofii i teologii Warszawa: Filozofia dialogu". Warsaw.

Gara J. (2009), Od filozoficznych podstaw wychowania do ejdetycznej filozofii wychowania. Warsaw.

Gromkowska-Melosik A. (2007), Społeczno-kulturowe aspekty nieuczciwości szkolnej i akademickiej, in: Gromkowska-Melosik A., Ściągi, plagiaty, fałszywe dyplomy. Sopot.

Krauze-Sikorska H. (2014), Mikro- i makrokontekst w procesie systemowej diagnozy psychopedagogicznej dzieci i młodzieży z trudnościami w uczeniu się. "Studia Edukacyjne" No. 33/2014, pp. 19-33.

Krzyżanowski J. (1984), Nauka o literaturze. Wrocałw-Warszawa-Kraków-Gdańsk-Łódź.

Kulmowa J. (1971), Aporemy czyli rozmyślania przed lustrem. Warsaw.

Kulmowa J. (2006), Co się komu śni, a nawet i nie śni. Warsaw.

Kulmowa J. (1998), Dębołki. Warsaw.

Kulmowa J. (2001), Zagapienie. Gdańsk.

Mader J. (2003), Filozofia dialogu, transl. by Kijowski R. "Dominikańskie Studium Filozofii i Teologii w Warszawie: Filozofia Dialogu". Warsaw.

Materne A. (2017), Genius loci a samowychowanie estetyczne, in: H. Krauze-Sikorska, M. Klichowski, Świat małego dziecka. Poznań.

Melosik Z. (2002), Globalny nastolatek. (Re)konstrukcja tożsamości w ponowoczesnym świecie. "Horyzonty wychowania" No. 2/2002.

Rosenzweig F. (2003), Gramatyka Erosa (mowa miłości), transl. by Gadacz T. “Dominikańskie studium filozofii i teologii w Warszawie: Filozofia dialogu". Warsaw.

Słonimski A., Tuwim J. (1990), W oparach absurdu. Warszawa.

Smolińska-Theiss B. (2014), Korczakowskie narracje pedagogiczne. Krakow.

Świrko-Pilipczuk J. (2011), Samodzielność w filozoficznych poglądach i koncepcjach człowieka implikacje pedagogiczne. Szczecin.

Tarnowski K. (2015), Dialogiczna metafizyka Józefa Tischnera, [in:] Ks. Jarosław Jagiełło (ed.), Spory o naturę człowieka. Józefowi Tischnerowi w 15. Rocznicę śmierci. Kielce.

Wysocka E. (2004), Hermeneutyka, [in:] Pilch T. (ed.), Pedagogical Encyclopedia of the 21st century. Warsaw, Vol. II. 